\title{
Rethinking the History of the Käma World in Early India
}

\author{
Daud Ali
}

Published online: 4 January 2011

(C) Springer Science+Business Media B.V. 2010

\begin{abstract}
This essay introduces a special issue on the history of kāmaśāstra in medieval India. It briefly reviews the secondary scholarship on the subject from the publication of the first translations of the genre at the end of the nineteenth century. It highlights the relatively unexplored history of later kamaśāstra, and stresses the need for contexualized and detailed studies of the many kāmaśāstra treatises produced in the second millennium CE. The introduction, and the essays that follow, also argue for an expanded interpretive framework for the genre, moving beyond 'sex' and 'sexuality,' to a more widely defined notion of a 'kāma world', in which sensual pleasure is understood as being deeply enmeshed with aesthetic, ethical and cosmopolitan cultures.
\end{abstract}

Keywords Kāma $\cdot K \bar{a} m a s ́ a ̄ s t r a \cdot$ Pleasure - Sexuality · Aesthetics · Ethics · Michel Foucault · Cosmopolitanism

Although examination of the sensible, sensual world of material reality formed a substantial component of premodern South Asian intellectual concern, texts that treat of such subjects have been largely understudied by modern scholars of South Asia. They have occasionally been used to shore up popular images of ancient India-from colonial theories of oriental debauchery to romantic visions of India's mystical erotic arts-but rarely have they received serious historical and analytical scrutiny. The articles in this special issue hope to make an initial attempt to remedy this situation by exploring knowledge practices organized around what we would like to call the 'kāma world' of early India. Within this world of art and music, precious gems and metals, colorful flowers, luxurious fabrics, and enticing

D. Ali $(\bowtie)$

Department of South Asia Studies, University of Pennsylvania, 820 Williams Hall,

36th and Spruce Streets, Philadelphia, PA 19104, USA

e-mail: daudali@sas.upenn.edu 
perfumes, the urbane, cosmopolitan sophisticate cultivated his or her physical, mental and affective capacities in order to succeed in experiences of 'pleasure' - which included the creation and enjoyment of beauty, the experience of passion and attachment, and the pursuit of courtship and seduction. The papers here contend that the literatures on pleasure, so conceived, were far more consequential in their implications for the lives of the elite in early India and more connected to wider domains of cultural practice than has been hitherto appreciated. The papers demonstrate that these sources have much to offer cultural and intellectual historians when submitted to nuanced contextualization and theoretically informed interpretation.

Together, the essays in this issue advance the study of kāmaśāstra in several ways. First, they widen the scope of enquiry in relation to käma by postulating a wider range of practices that fall within its domain. Past commentators have generally understood the literatures of kāma to be concerned strictly with acts related to sex and erotic love. This approach ignores a vast set of concerns within this literature which linked sexual pleasure with diverse issues, from domestic life, friendship and gender to material culture, cosmetics, and gardens. In the Kämasūtra, only one of its seven books treats the sex act itself. Later manuals likewise have much interaction with diverse domains of knowledge. We therefore propose a "kàma world' over a conceptualization of kāma as sex or sexuality plain and simple. Second, the papers examine how the dynamics and contours of this world changed over time - both in practice and discourse - and suggest possible explanations for these transformations. Existing studies of kämaśāstra have typically either confined themselves to a single text or merely noticed the difference between one text and the next rather than raise any questions about the evolution of the genre. ${ }^{1}$ Third, the essays explore the changing interfaces between kāma and other aesthetic practices-some literary and some non-literary-which formed its 'supports.' As we shall see, kāma was envisioned as a concern explicitly connected to a vast array of aesthetic activities and enjoyments, from perfume and ornaments to games and

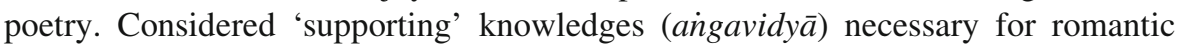
accomplishment in the Kämasūtra, they were also widely understood as 'arts' $(k a l \bar{a})$. Finally, the articles here implicitly address the wider significance of this kāmaśāstra as a whole, as well as the challenges and promises it offers in relation to key problems in the social and intellectual history of South Asia.

The justification for such an expanded purview is justified by the kāmaśāstra texts themselves. In opening up the purview of käma to such a diverse range of aesthetic practice, the papers presented here hope to evoke, collectively, a 'world' which the authors feel manifestly palpable in the textual sources, though one which has been sidestepped by scholars whose concerns have been driven by different topical interests. Such historical evocations can sometimes run the risk of distortion in their reliance on particular sources (while implicitly de-emphasizing others). They also may portray given contexts with far greater coherence than may be sustainable. Some might even argue that any attempt to 'recreate' a world from the past is potentially epistemologically naïve, always conveying more about the world of the authors than that of their subject of study. The papers here are very aware of

\footnotetext{
${ }^{1}$ For a brief account of studies to date, see Wojtilla (1998).
} 
the restricted provenance and rarefied contexts of the 'world' evoked by Sanskrit sources on aesthetics and pleasure. Yet this world of thought and practice, we contend, was far from inconsequential or trivial. Indeed, the aesthetic practices of elites in South Asia, as elsewhere, in time spread in complex ways far beyond the confines of the aristocracy, becoming both the basis and counterpoint for the emergence of later forms of aesthetic practice. And once again, conceiving of aesthetics as a practice extending beyond the formalist and literary preoccupations of much writing on the subject may help us understand these processes of dissemination and negotiation, though they do not form the specific concerns of the papers presented here. We also do not conceive of the kāma world as a historically static and seamless entity, but one that changed substantially over time. Characterizing and understanding the shifting contours of this world are of central importance to at least two of the essays here. Whether we present a world more akin to our own preoccupations than those of the texts, is of course a difficult question, one which is perhaps unanswerable. Yet we feel strongly that the texts vindicate our intertexual and outward looking approach. We hope that it will add a substantially new perspective and impetus for the study of these texts. A brief review of past scholarship on kāma and kāmaśāstra will suggest why this is the case.

The earliest European interpretations of kämaśāstra were made by Orientalist translators. Sir Richard Burton and Foster Fitzgerald Arbuthnot published translations of the Kämasūtra and Anangaranga in the 1880s for private circulation under the auspices of the 'Hindoo Kama Shastra Society.' ${ }^{2}$ In the prefaces to these texts Burton and Arbuthnot, addressing an imaginary public for whom sexual morals were a matter of intense debate, made impassioned defenses for their publication against potential charges of lewdity. They claimed that their original intention had been to have the texts rendered into Latin to prevent their falling into the hands of the vulgar, but on further reflection, were convinced that there was nothing immoral in them and that they fared well against works by authors like Rabelais and Petronius widely available in Victorian London. ${ }^{3}$ They argued that the presentation of materials in their texts was more sober and realistic than those of their own society, which, overburdened by religious doctrines of sin, treated sex, when they managed to do so at all, either 'jocularly', or 'with a tendency to hymn the joys of immorality and the gospel of debauchery'. Arbuthnot and Burton presented kāmaśâstra as an alternative to Victorian moral excess and compared the work to controversial scientific manuals on domestic life, female physiology, and sex published in nineteenth-century England by medical doctors. ${ }^{5}$ Moreover, they felt that such texts could, as ethnographic documents, afford considerable advancement to the growing science of human sexual behavior. These two images, as exotica

\footnotetext{
${ }^{2}$ Doniger and Kakar, who provide an assessment of Burton and Arbuthnot's efforts (2002, p. li) point out that they probably did not translate these texts themselves, but were heavily assisted by Indian pandits. Also see Grant (2005) on the Orientalist framing of the text.

3 See Arbuthnot and Burton (1964, p. 16).

4 Arbuthnot and Burton (1964, p. 10).

5 Arbuthnot and Burton (1883, p. 6). On the texts cited, see McGrath (2002, p. 47 ff).
} 
recording the sexual habits of an Oriental civilization and as evidence of a nonwestern humanistic approach to sex, formed the dominant interpretive frames inherited by later generations of scholars, psychologists, and medical doctors who introduced the texts of the genre.

Within a decade of Burton and Arbuthnot's translation, the first printed editions of both the Anangaranga and the Kämasūtra appeared, and were followed in ensuing decades by the publication of other kāmaśāstra texts. At the same time, various studies appeared on the subject of sex and marriage customs in traditional India, relying on kāmaśāstra as well as other sources. ${ }^{6}$ The intellectual concerns of these works were typically derived, as with those drawn upon by Burton and Arbuthnot, from concern over the sexual customs and the role of women in traditional India-including not only on sexual behaviors but female physiology and psychology. To the extent that such research portrayed an overall assessment of women in ancient India, it was also drawn into debates in nationalist circles from the 1930s around the 'status of women' in Hindu civilization. Among the most notable of the earlier studies on sexual life in ancient India was Richard Schmidt's Beiträge zur Indischen Erotik (1911) which provided the first and to date most comprehensive survey of the genre of kämaśāstra, including an extensive list of works, (most unpublished at the time and cited from manuscript collections) followed by a topical survey of key subjects of the śāstra with relevant quotations from particular works.

As more kāmaśāstra texts were published in the first half of the twentieth century, two approaches to the genre crystallized which largely extended the attitudes of Burton and Arbhuthnot. On the one hand, scholars of ancient Indian history used kāmaśāstra texts, particularly the Kämasūtra, as sources in the first forays into the writing of social and cultural history of ancient India. This was attempted as early as 1929 by H. C. Chakladar in a ground-breaking work on social history in ancient India based on Vātsyāyana's Kāmasūtra. ${ }^{7}$ S. K. De's important study of love in Sanskrit literature, published in the same year, drew heavily on kāmaśāstra and a revised edition included a separate treatment of it. ${ }^{8}$ These works in many ways carried on the concerns of earlier scholars writing on the 'customs of the Hindus', but gradually introduced more refined analytical questions, historically grounded interpretive frameworks and complex models of society. A major topic which animated some of this literature, but which generated its own robust activity, was the status of women in early India. ${ }^{9}$ By the 1960 s social history was firmly established in the field and many scholars had adopted a more materialist framework toward sex and society. N. N. Bhattacharyya, writing in the 1970 s sketched a vast overview of sexual mores in ancient India, which from the outset eschewed 'the myth that Indian civilization was a concrete unity,' to argue that erotic literatures in India documented a gradual and uneven shift from pre-Aryan matriarchal social

\footnotetext{
6 See Schmidt (1904) and Meyer (1915) and for a much later work in this tradition, see Fišer (1967).

7 Chakladar (1929).

8 Both included in De (1959).

9 Inaugurated by Altekar (1938) and extended by various scholars. For a review of the literature and discusson of more recent feminist historiography, see Roy (1999a).
} 
organization to patriarchal structures under the influence of Vedic society. ${ }^{10}$ While such approaches served to provide richer contexts for kāmaśāstra, they sometimes also had the tendency to dismiss the concerns of the genre as the idle fantasies of a ruling or feudal class. ${ }^{11}$ More recently, however, studies of gender in early India have provided substantially more complex analyses of the role of sex, reproduction and the female body in the context of patriarchal structures, though they have less often focused on kāmaśāstra as a genre. ${ }^{12}$

The more prevalent interpretation of kämaśāstra, however, was unconnected to these historical studies. Following Burton and Arbuthnot, publishers cast them as Indian contributions to sexological science. Translators repeatedly emphasized their sober and scientific attitude, correlated their vocabulary with modern medical and anthropological lexicons, and often retained Burton's comparative notes on sexual customs in other cultures. More nationalistically inclined scholars hailed the practical and modern outlook of the kāmaśāstra authors that seemed to counter colonial arguments about the inherent otherworldliness of Indian intellectualism. In the 1950s and 60s the scientific credentials of these translations were presumably furthered by the inclusion of short epigrams in their front matter prescribing their sale to specialists, or, as one edition put it, to 'members of the medical and legal professions, scholars and research students of Indology, psychology and the social sciences. ${ }^{13}$ Other translations received the benefaction or active involvement of medical or psychiatric professionals. The major English translation of Kokkoka's Ratirahasya, for example, was undertaken by the noted gerontologist and sexologist Dr Alex Comfort, who provided it with an elaborate introduction. ${ }^{14}$ Such associations were particularly common in European and American editions during the 1960s and 70s, when elements of the medical establishment served as a sort of legitimizing voice for rapidly changing attitudes toward sex. This wider shift in attitudes, combined with the contemporary turn toward eastern spirituality, conspired to create a lively market for translations of Indian erotica. And all of this produced a seemingly heady vindication of Burton and Arbuthnot's original casting of these texts. Their prefaces routinely appeared alongside the scholarly accolades of doctors and psychologists in the introductory material of the many reprints of the Kāmasūtra and Anangaranga. These stereotypes even entered the filmic medium, when, in Girish Karnad's rendition of the Mrcchakațika, (Utsav, 1963), the venerable Vātsyāyana (author of the Kämasūtra) humoursly appears as an eccentric sexologist, peering into the portals of brothels with a notebook in hand!

The presuppositions of this framework, however, were implicitly called into question by the arguments of the French sociologist Michel Foucault in his unfinished History of Sexuality. Foucault argued that modern medical, psychological and

\footnotetext{
${ }^{10}$ Bhattacharyya (1975, p. 6).

11 See, for example, Bhattacharyya's scathing remarks on nāyikābheda and kāmasthāna (1975, pp. 104-105).

12 Notable exceptions are Roy (1998, 1999b) and to a lesser extent Shah (2002).

13 Included in Upadhyaya (1965, p. iv).

14 Comfort (1964, pp. 43-100), who went on to write the hugely popular and influential book The Joy of Sex (1972). Doniger and Kakar (2002, p. li, fn. 61) note that Comfort's translation was probably not his own.
} 
juridical knowledges conspired to make 'sexuality' a determinative feature of individual human development and identity. Modern scientific practices, then, did not so much discover, repress, or liberate human sexuality as much as they actually called it into being. He argued that this was a substantial transformation and reorientation of earlier attitudes and practices prevalent in the Christian West, and in later volumes of his history sought to analyze the place of sex within the conceptual and ethical frameworks of Hellenic and Roman societies. Focault's work inspired intense debate among scholars already working on issues of sex and sexual identity in classical and medieval western society, but had little impact on the study of kāmaśāstra. ${ }^{15}$ Though Foucault was not specifically concerned with non-European societies, he did make a broad historical distinction between what he called two 'great procedures for producing the truth of sex': ars erotica and scientia sexualis. ${ }^{16}$ While the latter of these, the 'science of human sexuality', was unique to the postmedieval West, Indian, Arab, Roman, and Chinese societies, for example, possessed traditions which understood sex as an 'art of pleasure'. The distinction between the two, according to Foucault, was that scientia sexualis and its antecedents sought the 'truth of sex' in the laws of the individual human body and psyche, whereas ars erotica drew the 'truth of sex' from pleasure itself, with its own interior logic and esoteric structure. Though Foucault's characterization of Indian discourses on sex is surely too generic, his wider distinction does underscore the historical novelty and specificity of scientia sexualis and its putative object of study, "sexuality. ${ }^{17}$ While kāmaśāstra surely had features of an organized and systematic knowledge and thus resembled a science in its looser sense, it was neither based on a strictly empiricist epistemology, nor was it exclusively concerned with the physiological, psychological, and behavioral aspects of sex. The idea that Vātsyāyana was a celebrant of ancient Indian sexuality or an Indian fore-runner to 'sexologists' like Havelock Ellis or Alex Comfort, thus, is not sustainable. ${ }^{18}$ Nor was kāmaśāstra and its allied knowledges linked to state institutions involved in the regulation of bodies and populations, a defining feature of modern 'sexuality' as described by Foucault. ${ }^{19}$ Even a basic familiarity with the early Indian materials immediately reveals that the institutional patronage, epistemological procedures, physiological, mental and moral assumptions, parameters of provenance, and sometimes even the practical ends of kāmaśāstra were often significantly different from those of modern psychology, medicine and sexology.

\footnotetext{
15 For Foucault-inspired debates on classical sexuality, see Halperin et al. (1990).

16 Foucault (1984, p. 57ff).

17 While Doniger and Kakar's (2002, p. xv) criticism of Foucault as Eurocentric is fair insofar as Foucault's remarks on non-Western traditions were largely programmatic and contrapuntal, their contention that kāmaśāstra shares elements of both scientia sexualis and ars erotica is less helpful. Recent attempts (Vanita and Kidwai 2001) to recuperate lesbian and gay identity and experience from early kāmaśāstra texts, while alerting us to important dimensions of same sex relations, are not entirely convincing.

18 On the epistemological operations of śāstra, see Pollock (1985).

19 The application of Foucault's notion of the medicalization of sexuality to early India by Sweet and Zwilling (1993, p. 607) is thus misplaced.
} 
What useful insights, then, does Foucault's History of Sexuality afford us? The suggestion of 'pleasure' as a rubric over 'sexuality' is fruitful. It helps us see that sexual pleasure in kämaśāstra texts was at once both less and more than what is usually denoted by the term 'sexuality' in modern understandings. Sex, for example, was not deemed fundamentally essential or formative for individual identity and was neither an attribute rooted in the deep recesses of the human personality nor a biological essence to be probed, confined, or liberated. Kämaśāstra texts tended to be framed by other concerns, the most general of which understood pleasure as one among three axiological arenas of human effort (known as the group of three, or trivarga, the others being politico-material gain and moral rectitude) which together were deemed to constitute an ethically complete life in the world. From this vantage point kāmaśāstra sought not to free human desires from social repression, but to provide an ethical/practical framework for the enjoyment of pleasures. The trivarga conceptualization was not an ethical vision without a history, and not one without its own inner tensions and debates. ${ }^{20}$ In some arenas sexual pleasure formed a topic of extended consideration and ideological investment. It is here that sex tended to be connected to other forms of knowledge, including wider discourses about pleasure and aesthetics typical of the courtly milieu. Sexual pleasure also came in later times to be associated with complex and sometimes esoteric anatomical maps of the body that connected to medical, astrological and religious knowledges. ${ }^{21}$ Throughout its history it is clear that kāmaśāstra addressed itself both to a restricted social milieu while at the same time authorizing a capacious set of wider objectives and supports. So despite its apparent autonomy as a sphere of human activity, kāma was not abstracted into a special, sui generis, category in and of itself, but instead formed part of wider practices of aesthetic, material and ethical self-transformation. This, we feel, should form the basis of the study of the genre and has prompted our call for a ' $k \bar{a} m a$ world'. Though there are several directions that beg further exploration from this perspective, the essays here take up two: the relation of kāma to other domains of aesthetic pleasure, and the changing contours of the field of kāmaśästra itself.

Approaching kamma as an aesthetic practice raises the complex issue of the relation of erotic love to early Indian aesthetic culture more generally. Though the close links between these domains have occasionally been remarked upon, ${ }^{22}$ recent work on Sanskrit literature gives us cause for revisiting this relationship. Sheldon Pollock's groundbreaking scholarship on Sanskrit literary culture in classical and medieval India, for example, has significantly broadened traditional perspectives on literature by focusing our attention on the inner dynamics and social world of literary production. ${ }^{23}$ New interpretive frameworks like 'literary culture' and metahistorical processes like 'cosmopolitanism' and 'vernacularization', have

\footnotetext{
20 The idea seems to have emerged in the smrti period, and śästras very frequently consider the relative ordering of these domains - with the overwhelming tendency to place dharma above the others. On the ordering of the trivarga, see Rocher (1985) and Malamoud (1996).

21 A recent study by Das (2003) explores changing docrines of conception in kāmaśāstra and āyurveda texts.

22 See Warder (1972, p. 11ff.) and De (1959, p. 104).

23 Presented in a number of articles, but most forcefully in Pollock (2006).
} 
substantially reinvigorated the field in ways which are still very much being worked out. Pollock's oeuvre has decisively shifted focus away from the traditional analytical objects of religion and the state by insisting on the importance and irreducibility of aesthetic production as an integral element of elite culture. This itself has significant implications for the analysis of käma. Yet Pollock's ideas of cosmopolitanism, vernacularization, and aesthetics more generally, have been consciously confined to the realm of the literary. There is, of course, some justification for this, as formal reflection on aesthetic experience was articulated most volubly in the extensive and well defined field of Sanskrit poetics (alaṇkāraśāstra). ${ }^{24}$ But poetics hardly exhausts the realm of aesthetics more generally, and numerous discourses survive which conceive of aesthetic pleasure as proceeding from wider conceptions of sensory phenomena. The essays here make the case for extending the parameters of aesthetic experience, and consequently those of analytical scrutiny, beyond the confines of self-conscious literature. They suggest that a diversity of aesthetic practices formed important elements of elite self-regard, and were closely articulated with a diverse array of material objects as well as social relationships of various kinds. By attention to these realms of aesthetic experience, particularly as they pertain to $k \bar{a} m a$ - and keeping in mind their close relations with literary realms - the articles here attempt to extend research on aesthetics beyond its existing boundaries and to refine some of the groundbreaking insights of recent literary study.

Accessing these realms of aesthetic experience, however, is a complex interpretive matter. This is the case for a number of reasons, not least being that erotic love formed the preferred subject of much literary composition. This of course underscores the importance of the topic for the 'mental structures' of early Indian society, and presents us with a panoply of highly mannered and conventionalized representations which themselves are worthy of study. But the relationships of such representations with social reality beyond these texts is often difficult to establish. Recourse to sāstric texts is useful here. On the one hand, poets and poeticians would seem to depend on conventions of kāma as found in kāmaśāstra. This is apparently confirmed by the treatises instructing poets, (alamkāraśāstra) which deploy the same terminology to refer to lovers (nāyaka/nāyikā) used in the kāmaśāstra. Indeed, the authors of alamkāra treatises recommend the kāmaśāstra as one of the knowledges to be mastered by the competent poet, and commentators to Sanskrit literary works often display this knowledge. Moreover, as Patel demonstrates in his paper in this issue, the categories of kāmaśāstra were even deployed as critical schema for thinking about canon specification among literary critics and commentators more generally. Yet it would be overly simplistic to assume that the relationship was one way, for many early kāmaśāstra texts not only include poetic virtuosity as a supporting knowledge for the pursuit of kāma, but borrow heavily from literary conventions in their own theories about love and lovers. Ali demonstrates the ways in which the author of the Nägarasarvasva borrows heavily from literary traditions to supplement categories long familiar to kāmaśāstra. The relation between the genres was so close that some later kāmaśāstra texts like the

$\overline{24}$ See particularly the treatment of the subject in Pollock (2001). 
Kämasamūha actually incorporate substantial numbers of subhāsitas from the kāvya traditions alongside traditional kāmaśāstric material. The entanglement between the realms of literature and kâma, thus, is deep and mutually constitutive.

There are of course other realms of sensual pleasure integral to the käma world to which discourses on poetics (alamkāraśāstra) were largely indifferent, but that were nevertheless pervasive in poetry itself. Here we may note the vast array of domains of body and material culture, including perfumes, exotics, horticulture, fabrics, foods, gems, ornamentation, cosmetics, unguents and coiffure, as well as specific practices, including processions, games, conversation, the use and interpretation of signals, the taking of wine and betel nut. While none of these realms generated a philosophically reflective discourse about aesthetic appreciation, they were nevertheless integral to the sensual experience of elites-poetic representations depict them as major preoccupations of the courtly nobility. Many formed the subject of distinct sāstric treatises while others were included in the courtly and sumptuary compendia for kings and nobles composed throughout the second millennium CE. An earlier generation of scholars took interest in these worlds, and we hope to rekindle interest in these knowledges and practices as part of a more diversely conceptualized aesthetic culture in early India. ${ }^{25}$ McHugh's essay in this volume draws our attention to a particular preoccupation of some kāmaśāstra texts which was shared by other medieval sumptuary and liturgical manuals: the acquisition and use of exotic commodities. These objects were not only themselves subject to a discourse of connoisseurship, but were closely imbricated with notions of power and cosmopolitan consumption. McHugh's essay makes it clear that any notion of aesthetics in medieval India must take into account this material world.

The other subject which these essays hope to address is the history of kāmaśāstra as a distinct field of knowledge. Presently, any such endeavor must be tentative at best, given our current knowledge of the texts and traditions in question. Despite the pioneering work done by Schmidt a century ago, only a handful of texts have been available in print until very recently - and our understanding of their provenance, authorship and chronology is often highly uncertain. ${ }^{26}$ Moreover, the study of kāmaśāstra has been dominated by work on Vātsyāyana's Kāmasūtra, which has had the effect of obscuring the very substantial number of kāmaśāstra texts that survive from later times. ${ }^{27}$ The Kämasütra's prominence is partly because it has been touted as the earliest and most authentic specimen of the kāmaśāstra discovered to date. ${ }^{28}$ It is also because the Kämasūtra was associated with the humanist values of 'classical' India rather than the degenerate traditions of later, medieval times. ${ }^{29}$ The later kāmaśāstras, to the extent that they have come under any scrutiny

\footnotetext{
25 See Gode (1960-) and Agrawala (1969).

26 Important is the publication of Shastri (1967).

27 The only exception to this is the encyclopedic work of Schmidt (1922). Bhattacharya (1975, pp. 102-122) and Comfort (1964, pp. 83-107) have very brief discussions of later literature.

28 The Kämasūtra names a number of earlier authorities which have not survived as separate works, thought they continue to be mentioned by later works in the field. For a treatment of pre-Vātsyāyana works, see Agrawala (1983).

29 See the remarks of Gupta (2002, p. 47).
} 
at all, have been deemed demotic, vulgar or even puritanical renditions of an earlier classical tradition marked by an open vision toward human sexuality. W. G. Archer, in introducing Comfort's translation of the Ratirahasya, asserts that in medieval India, with the living conditions being 'much harsher. . .Morals were tighter. There was more strain'. ${ }^{30}$ Such interpretations have relied heavily on tropes of 'medieval decline', Islamic moral conservatism, and later even ideas of Victorian prudery which have long been complicated and challenged by historians. With renewed research and interest in culture and society in the second millennium $\mathrm{CE}$, these narratives seem more like substitutes than tools for deeper analysis.

One important point worthy of reconsideration is the pre-eminent status given to Vātsyāyana's Kāmasūtra in the history of kāmaśāstra. When colonial authors encountered this literature, it was the later treatises that constituted the standard configuration of knowledge on kamma. Indeed, the first text encountered (and published by) Burton and Arbuthnot, under the title Kāma Śāstra, was not the Kāmasūtra, but a fifteenth-century treatise, the Anangaranga by Kalyānamalla. In a later release of this work under its proper title, the translators noted that it was commonly called 'Koka Pandit' after a popularly ascribed author and that 'lithographed copies have been printed in the hundreds of thousands, and the book is in the hands of both sexes and all ages, throughout the nearer East and possibly it may extend to China and Japan. ${ }^{31}$ While the latter of these claims may be difficult to substantiate, together they suggest two points. First, that by the end of the nineteenth century there seems to have been a conflation between Kalyānamalla and Kokkoka, author of the more widespread work known as the Ratirahasya. This conflation was noticed by Schmidt, writing several years later, who observed further that the authorship of Kokkoka or 'Koka' was so popular that the term 'Kokaśāstra' came to denote the genre of kāmaśāstra itself. ${ }^{32}$ Second, and more importantly, the Ratirahasya, Anaingarainga and other later treatises seem to have circulated very widely and held great influence. This is clear enough from Schmidt's work, which noted a vast array of texts using manuscripts and manuscript catalogues. Some of these later texts were also translated into vernaculars. Often associated with the name 'Koka', they appeared in popular print editions and pamphlets in the early twentieth century-and had their own interesting histories in the emerging vernacular language public spheres. ${ }^{33}$

Indeed, while Vātsyāyana and his Kämasūtra were not unknown, treatises like the Ratirahasya and Nāgarasarvasva seem to have exerted more influence throughout the second millennium both within and beyond the kāmaśāstra tradition. ${ }^{34}$ Literary commentaries written in the thirteenth and fourteenth centuries, for example, routinely cite these texts rather than the Kamasütra when referring to

\footnotetext{
30 Archer (1964, p. 21). For a more recent (and sweeping) version of this argument, see Zysk (2002, pp. 4-5).

31 Arbuthnot and Burton (repr. 1964, pp. 14-15.).

32 Schmidt (1922, p. 64); see aslo Comfort (1964, p. 54).

33 For a discussion of sex manuals published in Hindi, see Gupta (2002, pp. 49-66, esp. p. 53, fn. 80).

34 The sixteenth-century Kandarpacudāmaṇ̄, for example, was a verse rendition of Vātsyāyana's treatise.
} 
technical aspects in kāmaśāstra. ${ }^{35}$ When the fifteenth-century poet Ananta compiled his Kāmasamūha ('Anthology on Kāma') from earlier authorities, he included substantial material from the Ratirahasya and Nāgarasarvasva, but none from Vātsyāyana's text. ${ }^{36}$ One reason for this may have been a change in the style of kāmaśāstra texts. While Vātsyāyana's text is a sūtra composition consisting mostly of short prose sentences (with occasional verses at the conclusion of each chapter), the vast majority of later kāmaśāstras are composed entirely in verse. ${ }^{37}$ It would seem that like nittiśāstra, the latter day history of kāmaśāstra was stylistically and thematically intertwined with the growth and evolution of kāvya. Their verse form made them more prone to extraction, citation, and circulation and it is thus not surprising that medieval subhāsita anthologies included verses from the authors of these treatises considerably more frequently than material from the Kämasūtra. ${ }^{38}$ Indeed, it could be argued that $\mathrm{t}$ is through such verses that kāmaśāstra retained strong avenues of interaction with other spheres of literary and intellectual production.

This inversion of chronological emphasis within the tradition demands greater attention to world of medieval kāmaśāstra. It has long been noted that new categories of lovers, concepts of the body and magical doctrines seem to be introduced into later texts. Recently, Kenneth Zysk has even proposed the emergence of a related but distinct tradition of 'ratiśâstra' centered around the conjugal couple and reproduction. ${ }^{39}$ The essays of Desmond and Ali take two different methodological approaches to the problem of accounting for change within the kāmaśāstra tradition. Desmond surveys the vast panoroma of kāmaśāstra and the changing subjectivities that it interpolated over time, while Ali looks closely at a single text, the Nägarasarvasva of Padmaśrī, to assess the configuration of the saastra and its relations to other knowledges, particularly aesthetic and tantric knowledges, at a particular moment in time. Both essays are concerned with the changing relations between kāmaśāstra and the social world as well as its relationship with other fields of knowledge and practice.

\section{References}

Agrawala, P. K. (1983). The unknown Kamasutras: Being an anthology of the ancientmost love-aphorisms of seers of the tradition and its expositors. Varanasi: Prithivi Prakashan.

Agrawala, V. S. (1969). The deeds of Harsha: Being a cultural study of Bāna's Harshacarita. Varanasi: Prithvi Prakashan.

Arbuthnot, F. F., \& Burton, R. (1883). Preface. In F. F. Arbuthnot \& R. Burton (Trans.), The Kama Sutra of Vatsyayana. London: Hindoo Kama Shastra Society.

Arbuthnot, F. F., \& Burton, R (repr. 1964 [1885]). Preface. In F. F. Arbuthnot \& R. Burton (Trans.), The Ananga Ranga or the Hindu art of love. New York: Lancer.

\footnotetext{
35 These citations are frequently mentioned in discussions about the dating of later kāmaśāstras. See entries for specific texts in Schmidt (1922).

36 See Pathak (2008, pp. 254-266).

37 A shift which may be noticed in various śāstric literatures, most notably nīti/artha. Notable exceptions include the unusual but probably comparatively recent and related texts Pauravamanasijasūtra and Kādambarasvīkaranasūtra attributed to king Pururavas

38 Compare, for example, the appearance of verses in medieval anthologies attributed to Kokkoka and Padmaśrī to those attributed to Vātsyāyana. Sternbach (1978, s.v.).

39 See Zysk (2002, pp. 9-14).
} 
Archer, W. G. (1964). Preface. In A. Comfort (Trans.), The Koka Shastra: Being the Ratirahasya of Kokkoka and other medieval indian writings on love. London: Allen and Unwin.

Bhattacharyya, N. N. (1975). A history of indian erotic literature. Delhi: Munshiram Manoharlal.

Chakladar, H. C. (1929). Social life in ancient India: Studies in Vātsyāyana's Kāmasūtra. Calcutta: Greater India Society.

Comfort, A. (Trans.). (1964). The Koka Shastra: Being the Ratirahasya of Kokkoka and other medieval indian writings on love. London: Allen and Unwin.

Das, Rahul, P. (2003). The origin of a life of a human being: Conception and the female according to ancient indian medical and sexological literature. Delhi: Motilal Banarsidass.

De, S. K. (1959). Ancient indian erotics and erotic literature. Calcutta: Firma K.L. Mukhopadhyay.

Doniger, W., \& Kakar, S. (2002). Introduction. In W. Doniger \& S. Kakar (Trans.), The Kamasutra. Oxford: Oxford University Press.

Fišer, I. (1967). Indian erotics of the oldest period. Praha: Universita Karlova.

Foucault, M. (1984). The history of sexuality, Vol. 1: An Introduction. (R. Hurley, Trans.). New York: Penguin.

Gode, P. K. (1960, 1961, 1969). Studies in indian cultural history (3 Vols.). Horshiarpur: Vishveshvaranand Indological Institute.

Grant, B. (2005). Translating the Kamasutra. Third World Quarterly, 26(3), 509-16.

Gupta, C. (2002). Sexuality, obscenity, community: Women: Muslims and the Hindu public in colonial India. New York: Palgrave.

Halperin, D., Winkler, J., \& Zeitlin, F. (Eds.). (1990). Before sexuality: The construction of erotic experience in the ancient greek world. Princeton, NJ: Princeton University Press.

Malamoud, C. (1996). Semantics and rhetoric in the Hindu hierarchy of the 'aims of man'. In C. Malamoud (Ed.), Cooking the world: Ritual and thought in ancient India. Delhi: Oxford University Press.

McGrath, R. (2002). Seeing her sex: Medical archives and the female body. Manchester: Manchester University Press.

Meyer, J. J. (1915). Das Weib im Altindischen Epos. Leipzig: Heims.

Pathak, A. S. (Ed. and Trans.) (2008). Kāma Samūha of Srī Ananta Kavi. Varanasi: Chaukhambha Sanskrit Samsthan.

Pollock, S. (1985). The theory of practice and the practice of theory in Indian intellectual history. JOAS, 105(3), 499-519.

Pollock, S. (2001). The social aesthetic and Sanskrit literary theory. Journal of Indian Philosophy, 29, 197-229.

Pollock, S. (2006). The language of the gods in the world of men: Sanskrit, culture, and power in premodern India. Berkeley: University of California Press.

Rocher, L. (1985). The Kāmasūtra: Vātsyāyana's attitude toward Dharma and Dharmaśāstra. JOAS, 105(3), 521-29.

Roy, K. (1998). Unraveling the Kamasutra. In M. E. John \& J. Nair (Eds.), A question of silence: The sexual economies of modern India. Delhi: Kali for Women.

Roy, K. (Ed.). (1999a). Women in early indian societies. Delhi: Oxford University Press.

Roy, K. (1999b). The King's household: Structure/space in the Sastric Tradition. In U. Chakravarti \& K. Sangari (Eds.), From myths to markets: Essays on gender. Delhi: Manohar, IIAS.

Sastri, D. (Ed.). (1967). Kāmakuñjalatā (A collection of rare works on Kāma śāstra). Varanasi: Chowkhambha Sanskrit Series Office.

Schmidt, R. (1904). Liebe und Ehe im alten und modernen Indien. Berlin: Verlag von H. Basdorf.

Schmidt, R. (1922 [1911]). Beiträge zur Indischen Erotik: Das Liebesleben des Sanskirt Volkes. Berlin: Verlag von H. Basdorf.

Shah, S. (2002). In the business of Kama: Prostitution in classical Sanskrit literature from the seventh to thirteenth centuries. Medieval History Journal, 5(1), 121-56.

Shastri, D. (1967). Kāmakuñjalātā. Varanasi: Chaukhamba Sanskrit Series.

Sternbach, L. (1978). A descriptive catalogue of poets quoted in sanskrit anthologies and inscriptions (2 Vols.). Wiesbaden: Otto Harrassowitz.

Sweet, M., \& Zwilling, L. (1993). The first medicalization: The taxonomy and etiology of queerness in classical Indian Medicine. The Journal of the History of Sexuality, 3(4), 590-607.

Upadhyaya, S. C. (1965). The Hindu secrets of love: Kokashastra (Rati Rahasya) of Pandit Kokkoka. Bombay: D. B. Taraporevala Sons and Co.

Vanita, R., \& Kidwai, S. (2001). Same-sex love in India: Readings from literature and history. Delhi: Macmillan.

Warder, A. K. (1972). Indian Kāvya literature (Vol. 1). Delhi: Motilal Banarsidass. 
Wojtilla, G. (1998). Kāmaśāstra-A short report on stand, methods, and tasks of researh. In J. Vace \& J. Dvorak (Eds.), Trends in Indian Studies: Proceedings of the ESIS. Prague: Charles University Press.

Zysk, K. (2002). Conjugal love in India: Ratiśāstra and Ratiramaṇa. Leiden: Brill. 